VS Publications

Alford Council of International English \& Literature Journal(ACIELJ)

Impact Factor:4.401(SJIF)An International Peer-Reviewed English Journal

www.acielj.com

Vol-3,Issue-2 ,2020

ISSN:2581-6500

\title{
AESTHETIC INSTRUMENTALISM IN OSCAR WILDE'S THE HAPPY PRINCE
}

\section{Arfa Noor}

Pakistan

Aesthetic Instrumentalism in Oscar Wilde's "The Happy Prince"

\section{Abstract}

This paper attempts to see Oscar Wilde's short story "The Happy Prince" Aesthetically. The researcher is applying the theory of Aesthetic Instrumentalism to help the readers to read the satiric short story "The Happy Prince" with the lens of Aesthetics. The researcher's utmost aim is to dig out Oscar Wilde's concept of Aestheticism through the story. Wilde gave some more heights to Aesthetics which can be seen in his writings. The researcher critically analyses the short story and other related articles to it. The researcher focuses on those points in the short story which shows the Aesthetic Instrumentalism of Oscar Wilde. The researcher concludes with the idea that the Aesthetic Instrumentalism of Oscar Wilde gives deep essence of life to his readers.

Keywords: Oscar Wilde, Victorian age, The Happy Prince, Aesthetics, Aesthetic Instrumentalism.

\section{Introduction}

A Dublin playwright, poet and author, Wilde was among eminent literary personages of Victorian age, after graduating from Oxford University he taught basic principles of Aestheticism as a poet and critic. His most notable works are Picture of Dorian Gray, his only novel which he published in 1891. He wrote many plays as a dramatist like, "A Women of No Importance", "An ideal Husband", "The Importance of Being Earnest", including his satirical comedies like "Lady Windermere's Fan". Oscar Wilde was sincerely devoted to the Principles of Aestheticism and he lectured them in various occasions. According to Wilde “All art is at one surface and symbol."In his novel Dorian Gray, Oscar writes; "Those who beneath the surface do so at their peril.It is the spectator and not life, the art really mirrors diversity of opinion about a work." In late 19th century Aestheticism main motto was "art for art sake." Oscar Wilde had the ability to dig out all the evils of the society and stand against them through his work.

Though he was the main pillar of the Aesthetic movement but his concepts about Aestheticism were different from his co campaigners. Oscar Wilde was supporting the point of view of Lord Henry "a new hedonism." Oscar Wilde was upset by the societal changes due to industrializations which brought materialism on the board. After the arrival of materialism, the class distinction between poor and rich maximized and reached to its peak. Aesthetic is a branch 
VS Publications

Alford Council of International English \& Literature Journal(ACIELJ)

Impact Factor:4.401(SJIF)An International Peer-Reviewed English Journal

www.acielj.com

Vol-3,Issue-2 ,2020

ISSN:2581-6500

of philosophy which promotes the art, beauty and taste. Moreover, it is study of sensory-emotional values. The perception of beauty, art and taste is difficult in every individual. "Everyone has his own sense of taste." (Immanuel Kant, 1976.) The Theory of Aestheticism basic purpose is to see the art both physically and spiritually. Art has different shapes and types. To perceive different artworks different sub aesthetic theories are used to judge the art work. However, four Aesthetic theories are mainly applied to judge any artwork. Formalism, Emotionalism, Immitationalism and Instrumentalism. Formalism is the Aesthetic theory which emphasizes the art's visual qualities. Formalism deals with design and elements of art. Art comes in formalist artwork if it is successfully put in a visual heart catching design. Piece of painting comes in category of formalism due to its design and elements of art used in it. Emotionalism is the Aesthetic theory that stresses the expressive qualities of an art. Emotionalism gives priority to ideas, feeling, moods and communication with the viewers through them. The main purpose of the emotionalist artwork is to grab viewers' emotion and attention. The art in this category may have realistic look. An art will be considered as emotionalist if the emotions being expressed through it. Immitationalism is the Aesthetic theory that refers to those artworks which have realistic look. Immitationalism recognize those objects which we can see in real world. It is concern to bring the real art on the surface. Immitationalism is also known as representationalism due to its representation of the real world through art. Aesthetic Instrumentalism aims to influence society. Instrumentalism targets to bring change in the society through art. It contains a message or purpose. Aesthetic Instrumentalism could have traces of imitational, formal, emotional aesthetic qualities. Therefore, it synthesizes aesthetic reaction. Instrumentalism gives hope and considered as functional. Many artworks have the components that could be put in more than one category. Artist is meant to portray the real image of an object, to grab the emotional senses of the viewer and to influence the society through his art.

The Happy Prince is an allegory in which Wilde highlighted the social injustice of Victorian age. In the short story he told us that how the rulers in Victorian age neglected their people. Many were dying of hunger, health issues; poverty just because of the negligence of the ruling class. Sitting in the castle, no king can know the deplorable condition of the people. In The Happy Prince the same concept has been brought on the surface by Wilde. When the luxurious statue of the Prince decorated above the city then he came to know about the actual condition of the people that how they were ill-treated by the rulers. The Prince requested Swallow to stay with him, for sometime Swallow (bird) accepted his request and helped the Prince to reach to the poor and help them to come out of the sufferings. The story advocates the latent beauty of an individual. Every individual has a spark within it; it just needs to tear up the soul and to feel the suffering for others. The Prince had luxurious life but once he died, his people made his statue and locate that above the city. He got shocked when he saw the condition of his people. He got 
VS Publications

Alford Council of International English \& Literature Journal(ACIELJ)

Impact Factor:4.401(SJIF)An International Peer-Reviewed English Journal

www.acielj.com

Vol-3,Issue-2,2020

ISSN:2581-6500

that spark to feel for others and thus he attained immortality. The researcher aims to apply Aesthetic Instrumentalism on the characters of Prince and Swallow. In this paper the researcher will find traces of Aesthetic Instrumentalism in the short story The Happy Prince penned down by Oscar Wilde.

\section{Literature Review}

Numerous books, thesis, articles, volumes of journals and magazines are penned and publicized concerning the human life and nature as something very significant and unprecendant in the world. Oscar Wilde is much discussed by critics in various aspects which make him a prominent author of Victorian age. Let as throw light on some of the view of critics and researchers in respect to Oscar Wilde's The Happy Prince. Mitsuru Onda highlighted the subject matter and reason behind the Oscar Wilde's short story. Shilling Law worked on the Aesthetic aspect of Wilde's writing pieces. Likewise, Mathew Hofer and Gray recorded the lectures of Wilde and contributed to keep alive Wilde as a prominent figure of English Literature.

Mitsuru Onda (2002) gave as study to The Happy Prince by Oscar Wilde. He worked and highlighted the particular writing style of Wilde, the subject matter which he used for the discussion in his writing and most notably the cause of Oscar Wilde behind authoring the short story. Shilling Law (2006) wrote a research article under title "The Beautiful Untrue Things: The Fairy Tales of Oscar Wilde."In the article it is discussed that Wilde's short stories are actual representation of Oscar Wilde's Aesthetics and establishes a new sub genre; The
Aesthetic Fairy Tales. Hogskolan Dalarna (2007) worked on intended latent messages of the short story "The Happy Prince" sketched by Oscar Wilde. His work described the various translations of the short story. According to him almost 17 translations of Oscar Wilde's The Happy Prince in to Hebrew has been made in the years (1921-2008). Mathew Hofer and Gray Scharnhorst, University of Illinois Press URBANA AND CHICAGO (2010) .They published a book under the title Oscar Wilde in America which contains The Interviews of Wilde. Originally the lectures were recorded by Lewis and Smith. One other author E.H Michael recorder the interviews of Oscar Wilde in 1882 and published them in 1979 but most of the interviews had no relation with Wilde. In short, neither E.H Michael nor Lewis and Smith recorded the actual interviews by him. Mathew Hofer and Gray edited the original book and brought the actual words of Oscar Wilde to the people. Islam, Durba (2012) worked on the "Gain of Sufferings" in Oscar Wilde's short stories. His thesis aims to identify the reason behind the wide spread of Wilde's stories. He comes up with the conclusion that Oscar Wilde stories have new and unique concepts which leave the traditions behind. In the year (2013) Deborah Scheldt worked on the tragic mode in Oscar Wilde fairy tales. He discussed the tragic heroes, tragic villains, martyrs, issues of fate, regret, well power, self acknowledgement death and distress as well as the reversion of paradox, tragic structures which lead us to conclude that tragic mode is come out with and very potent in Wilde's fairy tales. Sadia M.H, Shahar Bano and M.F Tabbassum (2015) 
VS Publications

Alford Council of International English \& Literature Journal(ACIELJ)

Impact Factor:4.401(SJIF)An International Peer-Reviewed English Journal

www.acielj.com

Vol-3,Issue-2,2020

ISSN:2581-6500

worked together on stylistic analysis of short story The Happy Prince. They worked on areas of stylistics, satire, imagery, irony, allegory, symbolism in "The Happy Prince" particularly. The short story "The Happy Prince" has not been discussed with the perspective of Aesthetic Instrumentalism. The researcher is truly devoted to explore the unexplored beauty of the story.

\section{Discussion}

Time does not remain same in an individual's life. Concepts, perception of life changes with the upgrading life experiences. The Prince was known as The Happy Prince due to his happiness and pleasure he had in his luxurious life. He had human heart but he was kept in fence like castle, where he used to play with his companions. After his death, his statue was made to depict his happy life he had as a Prince. Throughout his life he never questioned what was behind the boundary wall of the castle. When he came out of that life and had been put in the form of a statue at the top of the city the unexpected aspects of his countrymen lives revealed to him. He notices that life was shedding tears and his people were malnutrition. The old women were thin faced and waiting for death to have mercy on them. Poverty had overtaken his state. It saddened him the most when he came to know that life inside the border and life outside the boundary wall of the castle had great difference in terms of luxuries and resources. At one side heartless humans were residing in luxuries having animalistic desires while on the other hand; behind the border the humans were having a bitter life more badly than animals and were waiting that one day death will come and will rescue them to the luxurious life of heaven. The Prince was first time regretting his life which he had under umbrella of luxuries, pleasures and calmness. He neither knew this aspect of life and nor he experienced. To him life was the centre of happiness and he had no concept of poverty in his conscious. It is hard to accept the sudden changes in thinking, priorities and most notably the misconceptions about life. $\mathrm{He}$ was fastened with a pole, he was unable to move. He was wishing to approach each and every needy and helps them to drag them out of the miserable life. His statue was located on the top of the city from where he was able to see all the people of the city below. He had an imaginative view about the world outside but his heart cried when he was pushing himself out of that imaginative world.

"His friends had long gone away to Egypt six weeks earlier than, but he had stayed behind, for he was in love with the most lovely Reed." He was tired of a long flight throughout the day. He was left behind of his fellows who took flight to Egypt. He left for his love, to see a glimpse of her. He was criticized for being in love with a mortal creature. He was sad that he would never have a single flight with her because she was domestic and she was not agreeing to leave her home. He used to fly in a circular way over the water to see her. He was used to listen the comments that his love would vanish once autumn strikes the country. He never took care of the soul piercing comments and loved her without any danger of the natural cycle. He missed the trip to Egypt just to express his feelings to her. "Then he noticed the statue at the tall column. 'i can 
VS Publications

Alford Council of International English \& Literature Journal(ACIELJ)

Impact Factor:4.401(SJIF)An International Peer-Reviewed English Journal

www.acielj.com

Vol-3,Issue-2 ,2020

ISSN:2581-6500

positioned up there,' he cried; 'it's far a fine

function with masses of fresh air.' So he alighted just among the feet of the Happy Prince." After a tiresome day he flies to search a suitable place to sleep and take some rest. He saw the statue and went there to sleep. He was happy that he will sleep under fresh air so he made a place for his sleep. As he lay down he felt a drop of water. At first he ignored but he experienced the same thing again. He was surprised that there were no single sign of rain on the sky than where the water is coming from and what was the purpose of the statue that it cannot stop droplets of water? He was about to leave that he had another droplet he looked above surprisingly.

He had a glimpse of the prince whose eyes were brimmed up of the tears. He was shocked and inquired him why is he weeping when he is famous by title of The Happy Prince. Your eyes have sapphire your sword-halt has Ruby; your body is made up of gold. Don't you have a golden life? The prince negated him and asked him to be his messenger and to stay with him for a night. The swallow denied that he is just here for his love Reed who lives beneath the sea; he could not stay with him. The prince started counting him the miseries, difficulties of the people around him and added that he wants to help them all but he could not move because he is fastened with the pole. 'Swallow, Swallow, little Swallow,' stated the Prince, 'will you not live with me for one night, and be my messenger? The boy is so thirsty, and the mom so unhappy. 'I don't assume i like boys,' replied the Swallow. 'Last summer season, when i used to be staying at the river, there have been impolite boys, the miller's sons, who had been constantly throwing stones at me" The swallow accepted his requisition and promised him to be with him for a night. The prince asked to take his Ruby from the sword to a sick boy nearby. The swallow denied by saying that I don't like boys because they hit me with stones when I fly over the sea. The Prince insisted by reminding him that what will they answer to their Lord after death. Their Lord will pay them back with something better than it. The Prince and the swallow had a treaty for a day to help the poor and needy of the city. Swallow would fly all over the city and would bring information about the needy to the people and the Prince would help them by giving piece of gold and other precious stones from his body, the swallow would take them to the people.

Though the prince lived a dark life in the castle where there was no concept of ethics and morality. The arrival of Industrialization and materialism snatched all the basic of ethics, morality and most surprisingly the pity feelings for others. The Happy Prince was brought up in the castle. He was of the view that world ends at the borders of the fence like castle. There is no life behind the fence he didn't know that poverty lives there. When he paced out of the castle after his death he met his fellow Swallow who had if not the same but not very different concepts about humanity. He lost his faith on humanity when he was hit by the boys while he was flying above the sea to meet his love Reed. The theory of Aesthetic Instrumentalism could be applied to both the characters of the short story. The Swallow killed his ego and agreed to the Prince to help the needy while on other hand The Happy Prince 
VS Publications

Alford Council of International English \& Literature Journal(ACIELJ)

Impact Factor:4.401(SJIF)An International Peer-Reviewed English Journal

www.acielj.com

Vol-3,Issue-2,2020

ISSN:2581-6500

who had luxurious life and never thought to go close to the poor and the poverty, killed his pride fullness and come forward to help those who were in need. He donated all gold and precious stones from his body. To him, outer beauty never meant when an individual does not have any inner beauty. He cursed the mind setup of the Victorians by giving away all precious stones of his body to the poor of the city. The most inspirational character is of the swallow that had lost faith on humanity due to heartlessness and compassionless attitude towards other creatures.

Though he had bad experience with humans but still in time of need he forget the unpleasant experience and stepped forward to help the poor with The Happy Prince. Every heart has a light within it. Every man and woman has been blessed with that specific light. It makes an individual shine spiritually and physically. Through it (Inner shine) the knowledge of physical and the spiritual are united. To find the light is the ultimate goal of every soul. From the cradle to grave man struggles for this specific kind of light for this unique kind of shine. To help others by killing your ego and pride fullness can earn an individual ultimate happiness, peace and inner beauty. The inner peace and inner beauty is the real outcome one can get from his life. It breaks out light in the soul of an individual and makes him immortal both physically and spiritually. The physical and spiritual beings are interlinked when the light of inner satisfaction pierce up the soul it automatically lightens up individual physically too and this physical shine also results in peace of mind. The short story
The Happy Prince is a minute try of the author to whisper in each and every individual's ear to know your worth and the light should pierce your body to give you happiness both spiritually and physically; as just physical beauty does not matter when an individual is deprived of inner beauty which leads one to inner satisfaction and immortality. Feeding the society with inner shine enlightens and influences the society for good.

\section{Conclusion}

This is fable which Oscar Wilde wrote for his kid but it got fame after publishing in his stories book "The Happy Prince and the Other Tales."The short story gives a message of sacrifice. The statue of the Prince was a symbol of hope for the poor of the city in one way or the other. It gives a deep essence and understanding of life. The story has beautifully mirrored the barbaric face of the humans, if any creature of God has heart full of feelings that is always other than human. The man has become iron headed and somewhere lost in materialism and in the valley of unattainable desires. Oscar Wilde was very much depressed by the Industrial revolution in Victorian age. The sudden change in the lives of elites and underprivileged made man far away from the actual term "life." The author of the story tried to awake the people of his time and educate him the real meaning of life which is hidden in helping each other and feeding well to the society.

Oscar Wilde, in the end of the story used strong dialogue between Angels and God. The God asked the angels "Bring me the two most precious things in the city," said God to one of His Angels; and the Angel brought Him the leaden heart and 
VS Publications

Alford Council of International English \& Literature Journal(ACIELJ)

Impact Factor:4.401(SJIF)An International Peer-Reviewed English Journal

www.acielj.com

Vol-3,Issue-2 ,2020

ISSN:2581-6500

the dead bird." When God met with the two precious souls $\mathrm{He}$ gave them good news that "You have rightly chosen," said God, "for in my garden of Paradise this little bird shall sing for evermore, and in my city of gold the Happy Prince shall praise me." The last dialogue between the God, The Happy Prince and Swallow is the stress relieving event for both the characters. If the Prince had not leaden his heart and the Swallow didn't meet with his death while serving God's creatures, they would have never got the protocol at the skies and immortality on the earth. It gives a lesson to the readers that no good intention goes in vain until and unless it is done with sincerity, pure heart and devotion.

\section{References:}

[1]The complete Illustrated Works of Oscar Wilde 2003 by Collins Classic.

David E. Fenner Introducing Aesthetics 2003.

[2]Kamran F.Z: An Anthology of short stories NUML Press, 2006 Pakistan.

Shilling Law, Ann, PhD, thesis, Loyola University, Chicago, 2006.

[3]Gradworks.umi.com/32/12/3212985.ht $\mathrm{ml}$.

[4]Hogskolan Dalarna "The Hidden Messages in Oscar Wilde's Happy Prince and The Debate on the Target Audience 2007.

[5]Islam, Durba, The Fairy Tales of Oscar Wilde and the gain of suffering, B A thesis, Brac University 2012

[6]Dalian Cohen Gross: The case of Hebrew Translations, SKASE Journal 2013.
Deborah Scheidt, Universidade Estadual de Ponta Grossa 2013.

[7]Sadia M.H, Shahar Bano, MF Tabassum (n.d.) stylistic Analysis 2015 of short story The happy Prince. www.Victorian web.org/history/class.html. 